Original Research Article

\title{
Screening of alcohol de-addiction potential of zinc: a study on albino rats
}

\author{
Priya Gandigawad ${ }^{1}$, Sharanabasayyaswamy B. Hiremath ${ }^{2 *}$
}

\begin{abstract}
${ }^{1}$ Department of Pharmacology, SDM Medical College, Dharwad, Karnataka, India ${ }^{2}$ Department of Pharmacology, Kodagu Institute of Medical Sciences, Madikeri, Karnataka, India
\end{abstract}

Received: 19 May 2017

Accepted: 24 June 2017

\section{*Correspondence to:}

Dr. Sharanabasayyaswamy B.

Hiremath,

Email: dr.sharan83@yahoo.com

Copyright: (C) the author(s), publisher and licensee Medip Academy. This is an openaccess article distributed under the terms of the Creative Commons Attribution NonCommercial License, which permits unrestricted noncommercial use, distribution, and reproduction in any medium, provided the original work is properly cited.

\begin{abstract}
Background: With regard to tobacco and alcohol addiction, involvement of NMDA receptors and glutamate as neurotransmitter has been highlighted. Few indirect evidences support possible de-addiction potential of zinc being mediated through their interaction with nicotinic and NMDA receptors. The objectives of the present study were planned to analyze the alcohol de-addiction potential of oral zinc sulfate as a monotherapy and as a supplement to topiramate, in male wistar albino rats.

Methods: Male wistar albino rats were exposed to 'two-bottle free choice' model of voluntary ethanol consumption, wherein each animal had access to water and $10 \% \mathrm{v} / \mathrm{v}$ ethyl alcohol in two separate bottles. Thirty male rats divided into five groups, each containing six rats were treated as control group, receiving $1 \mathrm{ml} / \mathrm{kg} / \mathrm{d}$ distilled water orally; zinc sulfate group receiving $18 \mathrm{mg} / \mathrm{kg} / \mathrm{d}$ of elemental zinc orally; topiramate group receiving topiramate $5 \mathrm{mg} / \mathrm{kg} / \mathrm{d}$, orally and Topiaramate plus Zinc sulfate group receiving both zinc sulfate $(18 \mathrm{mg} / \mathrm{kg} / \mathrm{d})$ and topiramate $(5 \mathrm{mg} / \mathrm{kg} / \mathrm{d})$ orally for two weeks.

Results: There were no significant differences with regard to all the three parameters in two-way ANOVA. However, there were significant differences with regard to amount of alcohol and water consumed but not API, in all the treatment groups in post-hoc test.

Conclusions: It is unclear on to the alcohol de-addiction potential of zinc as monotherapy and combination therapy with topiramate.
\end{abstract}

Keywords: Alcohol de-addiction, Topiramate, Zinc sulfate

\section{INTRODUCTION}

Alcohol addiction is a major global health and socioeconomic problem including in India. ${ }^{1,2}$ The approaches to treat a patient with alcohol addiction include use of disulfiram, topiramate, baclofen, naltrxone, acamprosate, ondensetran, verenecline, gabapentine. ${ }^{3}$ These individual drugs have their own drawbacks from the point of either cost or recurrence or adverse drug reaction or tolerability. Hence the search for a safe and simple drug for de-addiction or drugs with synergistic effect with existing drugs continues. This is important especially from the point of avoiding recurrence and safety. Zinc either as monotherapy or as an adjuvant has demonstrated beneficial effects in various CNS disorders ranging from anorexia nervosa, depression, anxiety, psychosis, epilepsy, etc. ${ }^{4,5}$ Zinc has specific modulator effect on the function and release of various CNS neurotransmitters like glutamate, GABA, serotonin, etc, through which it mediates these beneficial effects. ${ }^{6,7} \mathrm{With}$ regard to tobacco and alcohol addiction, involvement of NMDA receptors and glutamate as neurotransmitter has been highlighted in few studies. ${ }^{89}$ Few indirect evidences support possible de-addiction potential of zinc being mediated through their interaction with nicotinic and NMDA receptors. ${ }^{[8,9]}$ Considering all these evidences, especially NMDA based mechanism of zinc and 
magnesium; we aimed to screen the potential of zinc, present study was planned to analyze the effect of oral zinc sulfate as a monotherapy and as a supplement to topiramate, a proven drug for alcohol de-addiction.

\section{METHODS}

Study was conducted in the central animal house of the institute after the approval from Institutional Animal Ethics Committee. The $10 \%$ alcohol was supplied by institute and a flavoured alcohol was prepared in our department by adding fructose. Zinc sulfate and Topiramate were purchased from the NICE and INTAS Pharmaceuticals respectively through our pharmacy. Salt solution of zinc sulfate was freshly prepared just before administration by dissolving in distilled water. Male wistar albino rats weighing 200-300gms were used for this study. Animals were obtained from central animal house of department of Pharmacology of the institute, kept under standard laboratory conditions with free access to food and water. Thirty animals were selected and randomly divided into five groups, each containing six rats and treated as follows: control group receiving distilled water $(1 \mathrm{ml} / \mathrm{kg} / \mathrm{d}$, orally); Zinc sulfate group receiving $18 \mathrm{mg} / \mathrm{kg} / \mathrm{d}$, of elemental zinc orally; topiramate group receiving topiramate $5 \mathrm{mg} / \mathrm{kg} / \mathrm{d}$, orally and Topiaramate plus Zinc sulfate group receiving both zinc sulfate $(18 \mathrm{mg} / \mathrm{kg} / \mathrm{d})$ and topiramate $(5 \mathrm{mg} / \mathrm{kg} / \mathrm{d})$ orally.

Experiment was conducted in following four phases: Phase-1 (day1 to day 2): 'Acclimatization phase': Individual animals were isolated in separate cages with free access to water and food. All animals received two bottles with plain water. No drug treatment was done. Phase-2 (day 3 to day 6): 'Screening phase': 'Two-bottle free choice' model of voluntary ethanol consumption was used in this phase of the study. Here in this model one of the water bottles was replaced by bottle containing $10 \%$ v/v ethyl alcohol. All animals had access to and were allowed to drink $10 \% \mathrm{v} / \mathrm{v}$ ethyl alcohol ad libitum along with water provided in two separate pre-weighed bottles. Animals consuming less than $10 \mathrm{~g}$ of alcohol per day ('non-drinkers') were excluded from the study during this phase. Phase-3 (day 7 to 20): 'Treatment phase': All the animals received their respective allotted treatments. Animals were screened daily for the amount of alcohol and water consumed per day in terms of grams by weighing the bottles before and after giving access to alcohol and water. Daily change in body weight and volume of food consumed by each animal will be noted in terms of grams consumed per body weight. Phase-4 (day 20 to day 23): 'No-treatment phase': All drug treatments were discontinued with continued unrestricted access to alcohol, food and water.

Daily volume of alcohol and water consumed by each animal was noted in terms of grams per kg body weight. Mean and standard deviation values of daily volume of water and alcohol consumed in each test group were calculated in terms of $\mathrm{g} / \mathrm{kg}$ body weight of animal. Another parameter analyzed as an indicator of preference to alcohol was 'alcohol preference index' (API) calculated as 'volume of ethyl alcohol consumed (ml) / volume of ethyl alcohol consumed $(\mathrm{ml})+$ volume of water consumed $(\mathrm{ml})) \times 100$ '. These three parameters were used in statistical analysis to compare the differences between the groups by using two way ANOVA test followed by Tuckey's post-hoc analysis.

\section{RESULTS}

Table 1 and 2 shows the effects of test drugs on three parameters and their comparison with different test groups. There was lack any significant difference with regard to all the three parameters in two-way ANOVA. However, there were significant differences with regard to amount of alcohol and water consumed but not API in all the treatment groups in post-hoc test.

Table 1: Effects of test drugs on three parameters.

\begin{tabular}{|llllll|}
\hline & Control & Zinc & Topiramate & Zinc+Topiramate & P-value \\
\hline Alcohol consumed (g/kg Body Weight) & $264 \pm 182$ & $214 \pm 138$ & $270 \pm 195$ & $161 \pm 90.5$ & 0.615 \\
\hline Water consumed (g/kg Body Weight) & $266 \pm 202$ & $267 \pm 211$ & $191 \pm 179$ & $364 \pm 198$ & 0.572 \\
\hline API & $54.2 \pm 34.2$ & $43.2 \pm 31.8$ & $54.2 \pm 37.3$ & $47.5 \pm 34.5$ & 0.937 \\
\hline
\end{tabular}

API: Alcohol Preference Index, all values are in mean \pm SD. P-value using two way ANOVA

Table 2: Effects of test drugs on three parameters and their comparison with test groups.

\begin{tabular}{|llll|}
\hline & Alcohol consumed & Water consumed & API \\
\hline Control vs Zinc sulfate & $264 \pm 182$ vs $214 \pm 138^{*}$ & $266 \pm 202$ vs $267 \pm 211$ & $54.2 \pm 34.2$ vs $43.2 \pm 31.8$ \\
\hline Control vs Topiramate & $264 \pm 182$ vs $270 \pm 195^{*}$ & $266 \pm 202$ vs $191 \pm 179 *$ & $54.2 \pm 34.2$ vs $54.2 \pm 37.3$ \\
\hline Control vs Zinc+Topiramate & $264 \pm 182$ vs $161 \pm 90.5^{*}$ & $266 \pm 202$ vs $364 \pm 198^{*}$ & $54.2 \pm 34.2$ vs $47.5 \pm 34.5$ \\
\hline Zinc sulfate vs Topiramate & $214 \pm 138$ vs $270 \pm 195^{*}$ & $267 \pm 211$ vs $191 \pm 179 *$ & $43.2 \pm 31.8$ vs $54.2 \pm 37.3$ \\
\hline Zinc sulfate vs Zinc+Topiramate & $214 \pm 138$ vs $161 \pm 90.5^{*}$ & $267 \pm 211$ vs $364 \pm 198^{*}$ & $43.2 \pm 31.8$ vs $47.5 \pm 34.5$ \\
\hline Topiramate vs Zinc+Topiramate & $270 \pm 195$ vs $161 \pm 90.5^{*}$ & $191 \pm 179$ vs $364 \pm 198^{*}$ & $54.2 \pm 37.3$ vs $47.5 \pm 34.5$ \\
\hline
\end{tabular}

All values are in mean \pm SD. *P-value $<0.05$ (using Tuckey’s post-hoc test) 


\section{DISCUSSION}

Since we consider API as better index of alcohol deaddiction potential in this we believe that results of our study failed to show any conclusive evidence on the role of zinc sulfate and also topiramate. In addition we did not observed any signs of withdrawal reaction on the fourth phase of the study in any of the four groups including control group. This raises questions on to whether there was sufficient addiction developed to the alcohol. In addition, lack of beneficial effects of topiramate is also questionable since it has been proved to be effective in clinical trials. ${ }^{10}$ In individual group analysis using tuckey's post-hoc test, the results showed significant differences between individual treatment groups with regards to water and alcohol consumption but not API. Since the ANOVA and post-hoc tests answer different things, we could interpret as that individual groups significantly differ with each other with regard to amount of water and ethanol consumed but these differences may not be significant when all the four groups are compared. However, since there was no difference between individual groups with regard to API index, justification of de-addiction potential of zinc, topiramate or their combination doesn't seems justifiable.

There exists a complex interlinks between zinc and ethanol induced effects, both rewarding and physical. ${ }^{11}$ High levels of zinc may in fact enhance the rewarding and physical effects of alcohol which are mediated by glycine receptors, which need zinc as mediator for interaction between them. ${ }^{12-14}$ Further supplementation of zinc may in fact enhance ethanol mediated rewarding effects and thus potentiate its effects. ${ }^{15}$ So our idea of testing de-addiction potential of zinc based on its interaction with NMDA receptors may not be solid. Despite believing that the interaction of zinc at NMDA receptor inhibits the addiction to alcohol, perhaps this could have been nullified or superseded by its opposite effects on glycine receptor. With regard to topiramate, lack of its beneficial effects may not be surprising considering its inconsistent efficacy in various clinical trials. ${ }^{16}$ Though we do not justify our results by citing the negative trials of topiramate, the idea behind giving this reference is to imply the role of different factors that could have been responsible for the failure of zinc and topiramte in our study. To conclude, it is unclear on to the alcohol de-addiction potential of zinc as monotherapy and combination therapy with topiramate.

Funding: No funding sources Conflict of interest: None declared

Ethical approval: The study was approved by the Institutional Ethics Committee

\section{REFERENCES}

1. Ali SF, Onaivi ES, Dodd PR, Cadet JL, Schenk S, Kuhar MJ, et al. Understanding the Global Problem of Drug Addiction is a Challenge for IDARS
Scientists. Curr Neuropharmacol. 2011 Mar;9(1):2-7. Available https://www.ncbi.nlm.nih.gov/pmc/articles/PMC3137 181.

2. Pratima M, Manjunatha N, Subodh BN, Prabhat KC, Vivek B. Substance use and addiction research in India. Indian J Psychiatry. 2010;52:S189-99. Available https://www.ncbi.nlm.nih.gov/pmc/articles/PMC3146 212.

3. The addiction recovery guide. Your online guide to drug and alcohol ddiction recovery. 2017. Available at:

http://www.addictionrecoveryguide.org/medication/al coholism. Accessed on 19 May 2017.

4. Safai-Kutti S. Oral zinc supplementation in anorexia nervosa. Acta Psychiatr Scand. 1990;361:14-7. Available https://www.ncbi.nlm.nih.gov/pubmed/2291418.

5. Joshi M, Akhtar M, Najmi AK, Khuroo AH, Goswami D. Effect of zinc in animal models of anxiety, depression and psychosis. Hum Exp Toxicol. 2012;31:1237-43. Available at: https://www.ncbi.nlm.nih.gov/pubmed/22549093.

6. Du J, Zhu M, Bao H, Li B, Dong Y, Xiao C, et al. The Role of Nutrients in Protecting Mitochondrial Function and Neurotransmitter Signaling: Implications for the Treatment of Depression, PTSD, and Suicidal Behaviors. Crit Rev Food Sci Nutr. 2014;3:0. Available at: https://www.ncbi.nlm.nih.gov/pubmed/25365455.

7. Katalin T. Zinc in Neurotransmission. Annual Review of Nutrition. 2011;31:139-53. Available at: http://www.annualreviews.org/doi/abs/10.1146/annur ev-nutr-072610-145218.

8. Nechifor M. Magnesium and Zinc Involvement in Tobacco Addiction. J Addict Res Ther. 2012;S2:005. Available https://www.omicsonline.org/magnesium-and-zincinvolvement-in-tobacco-addiction-2155-6105.S2005.php?aid $=6610$.

9. Prior LP, Galduróz JC. Glutamatergic hyperfunctioning during alcohol withdrawal syndrome: Therapeutic perspective with zinc and magnesium. Medical Hypotheses. 2011;77:368-70. Available https://www.ncbi.nlm.nih.gov/pubmed/21645973.

10. Arbaizar B, Dierssen-Sotos T, Gomez-Acebo I, Llorca J. Topiramate in the treatment of alcohol dependence: a meta-analysis. Actas Espanolas de Psiquiatria. 2010;38(1):8-12. Available at: https://www.ncbi.nlm.nih.gov/pubmed/20931405.

11. Morud J, Adermark L, Ericson M, Söderpalm B. Alterations in ethanol-induced accumbal transmission after acute and long-term zinc depletion. Addict Biol. 2015;20(1):170-81. Available at: https://www.ncbi.nlm.nih.gov/pubmed/24102995.

12. McCracken LM, Trudell JR, Goldstein BE, Harris RA, Mihic SJ. Zinc enhances ethanol modulation of the alpha1 glycine receptor. Neuropharmacology 
2010;58(3):676-81.

Available https://www.ncbi.nlm.nih.gov/pubmed/2864772.

13. McCracken LM, Trudell JR, McCracken ML, Harris RA. Zinc-dependent modulation of $\alpha 2-$ and $\alpha 3$ glycine receptor subunits by ethanol. Alcohol Clin Exp Res. 2013;37(12):2002-10. Available at: https://www.ncbi.nlm.nih.gov/pubmed/4452379.

14. McCracken LM, Blednov YA, Trudell JR, Benavidez JM, Betz H, Harris RA. Mutation of a zinc-binding residue in the glycine receptor $\alpha 1$ subunit changes ethanol sensitivity in vitro and alcohol consumption in vivo. J Pharmacol Exp Ther. 2013;344(2):489-500. Available at:

https://www.ncbi.nlm.nih.gov/pubmed/3558822.
15. Kirson D, Cornelison GL, Philpo AE, Todorovic J, Mihic SJ. Physiological concentrations of zinc reduce taurine-activated GlyR responses to drugs of abuse. Neuropharmacology. 2013;75:286-94. Available at: https://www.ncbi.nlm.nih.gov/pubmed/23973295.

16. Medscape news and perspectives. Topiramate in the Treatment of Alcohol Use Disorders 2015. Available at: http://www.medscape.com/viewarticle/851686. Accessed 19 May 2017.

Cite this article as: Gandigawad P, Hiremath SB. Screening of alcohol de-addiction potential of zinc: a study on albino rats. Int $\mathrm{J}$ Basic Clin Pharmacol 2017;6:1977-80. 